
\title{
25 Research Sourere \\ Artificial Perches for Birds in Deforested Areas Favour a Seed Rain Similar to Woodland Remnants
}

Brenda Yamile Guidetti ( $\square$ guidettibrenda@gmail.com )

Consejo Nacional de Investigaciones Cientificas y Tecnicas https://orcid.org/0000-0002-9801-6048

\section{Sebastian Dardanelli}

INTA: Instituto Nacional de Tecnologia Agropecuaria

\section{Fátima María Lourdes Miño}

Universidad Autonoma de Entre Rios

\section{Guillermo César Amico}

Instituto de Investigaciones en Biodiversidad y Medioambiente

\section{Research Article}

Keywords: Deforestation, seed dispersal, birds, perches, non-native species, active restoration.

Posted Date: August 12th, 2021

DOI: https://doi.org/10.21203/rs.3.rs-700313/v1

License: (c) (i) This work is licensed under a Creative Commons Attribution 4.0 International License. Read Full License 


\section{Abstract}

The lack of seeds represents one of the highest difficulties to overcome for the ecological restoration of areas that have been deforested. This study evaluates the effectiveness of artificial perches in increasing the abundance and species richness of bird-dispersed seeds and the similitude of seed rain composition (origin and habit of plant seeds), of deforested areas with and without artificial perches in relation to woodland remnants that serve as seeds source. The experiment took place in two sites of the Espinal ecoregion, Argentina. We found that in deforested areas, perches increased seed abundance and species richness in the seed rain in comparison with deforested areas without artificial perches. The species composition under artificial perches was similar to the seed rain dispersed in the woodland. However, a decrease in the richness of native species was significant in the deforested area, probably due to behavioral differences between opportunistic and obligate frugivorous. Seed of trees and shrubs species were well represented in the seed rain under artificial perches. Results from this study contribute to the understanding of nucleation and recovery mechanisms used by nature that reflect ecosystem resilience. We recommend using artificial perches in deforested areas with potential for recovery because it is an efficient technique to promote the entry of birds and increase seed rain, preserving features of the original environment. However, using artificial perches should be avoided in sites with potentially invasive nonnative species.

\section{Introduction}

The lack of seed supply is one of the main barriers to overcome for ecological restoration in areas that have been deforested (Shoo and Catterall 2013; Elgar et al. 2014). In this sense, the role of many frugivorous birds species is essential in depositing seeds of the fleshy fruits consumed and in this way promote vegetation regeneration as they move towards the forest edges or degraded patches (Green and Dennis 2007). This contribution can be very significant in temperate regions where other groups of seeddispersing animals (i.e. reptiles and medium and large mammals) are not present or show marked decreases in their richness and abundances (Karubian et al. 2012). However, frugivorous birds find little incentive to move away or too far from the forest crossing open, deforested, or degraded areas, where fruit abundance is low and the chances of being caught by their predators are high (Mastrangelo 2014; Da Silveira et al. 2016). For this reason, deforested areas often receive negligible seed rain, even if they are surrounded by natural vegetation.

To overturn the resistance of birds entering deforested areas and dispersing seeds, some ecological restoration projects have been drawn upon to the installation of artificial perches for birds (Holl 1998; Zanini and Ganade 2005; Guidetti et al. 2016). Artificial perches increase structural complexity and stimulate birds to use open areas and stay there for longer times (Donald and Evans 2006; Pejchar et al. 2008). In addition, since seed deposition by defecation and regurgitation occurs more often when birds perch or immediately after they undertake flight (McDonnell and Stiles 1983), seeds tend to concentrate under isolated trees, live fences, or other remaining vegetation that has survived disturbances and it is used by birds as perch or rest points (Schlawin and Zahawi 2008; Pizo and dos Santos 2010; Cottee- 
Jones et al. 2015). In this way, artificial perches constitute a nucleation technique that allows the expression of recovery mechanisms used by nature (Schlawin and Zahawi 2008), reflecting the resilience of the ecosystem and prioritizing its bio-functionality (Sekercioglu 2007; Pejchar et al. 2008). The proper seed rain promoted by perches facilitates the establishment of small patches of plant regeneration (Guevara et al. 1992; Debussche and Isenniann 1994; Schleuning et al. 2011b). These patches of secondary forest reduce the contrast between logged areas and forest, and by naturally drift can occupy the empty spaces between them until integrating with the rest of the landscape (Reis et al. 2010).

Considering that landscape transformation due to agricultural activities affects more than $40 \%$ of the planet's land area and is the main cause of biodiversity and ecosystem services decline (Foley et al. 2011), ecological restorations measures need to be thought as the first alternative in those areas that have possibilities for recovery. Deforested areas that are not actively intervened can remain in intermediate successional states experiencing a very slow reversal towards the original ecosystem (Jones and Schmitz 2009). Otherwise, these areas can end up taking the form of a different ecosystem with a new species composition (Hobbs et al. 2006). The pioneer species dispersed by wind, mostly herbs and grasses, are best represented in deforested areas (Cubiña and Aide 2001; Zwiener et al. 2014). By contrast, late succession species rarely reach open areas or take too long to do so (Corlett and Hau 2000; Martínez-Garza and Howe 2003). Moreover, seeds of tree or shrub species are rapidly predated, tend to immediately germinate or die after a certain latency time (Hardwick et al. 2004). Consequently, after long periods of disturbance, it is unlikely that the pre-existing soil seed bank will contribute significantly to the regeneration of vegetation (Nepstad et al. 1996; Sione et al. 2016). On the other hand, active restoration actions such as direct seed planting in bare soil or reforestation plans, often fail in proper species selection (Griscom and Ashton 2011; Corbin and Holl 2012) or are performed with only one or a few species given the high costs involved (WWF International 2005; Corbin and Holl 2012). Instead, deforested areas with artificial perches for birds can recover the species of the original environment, through an ecological flow in which nearby forest remnants act as seeds source (Reis et al. 2010; Corbin and Holl 2012; Rocha-Santos et al. 2017).

Unfortunately, the barriers that get in the way of restoration processes are multiple and diverse. Areas recovering from disturbance may be more susceptible than mature ecosystems to invasion by nonnative species present in the landscape (Huebner and Tobin 2006; McCay et al. 2009). It can be considered as one disadvantage of the perches. Given that woody non-native plants with fleshy fruits dispersed by avian frugivorous are usually more successful in increasing their distribution range than other non-native and native plants, their dispersal under artificial perches is a point that must be considered (Ponce et al. 2012).

This study evaluates the effectiveness of artificial perches for birds in deforested areas of the center of the Province of Entre Ríos (Espinal ecoregion), Argentina, where the native woodland has potential for recovery. The questions to be answered are: 1 - do artificial perches increase the abundance and species richness of the seed rain dispersed by birds?, 2- does the origin (native or non-native) of the seed 
composition differ between the woodland remnants and under the artificial perches in deforested areas?, and 3- do artificial perches facilitate the arrival of woody species that then can act as natural perches in degraded environments?

\section{Materials And Methods}

\section{Study area}

The experiment was conducted in the subtropical woodland of the Espinal ecoregion. We selected two sites in the Paraná Department, in the center of Entre Ríos Province, Argentina (Fig 1), to perform the experiments. The two sites were more than 15 kilometers apart. The first site (PSM) was located in the

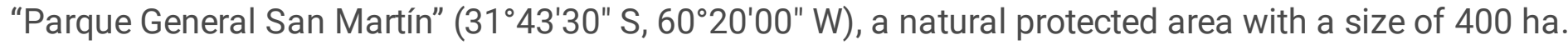
The second site (REA) was located in the "Reserva de Uso Múltiple Escuela J.B. Alberdi" (31 $50^{\prime} 12^{\prime \prime} \mathrm{S}$, $60^{\circ} 31^{\prime} 25^{\prime \prime} \mathrm{W}$ ), with a size of 20 ha. The woodlands of the region are low and xerophytic and vary from dense to open. There can be distinguished two tree stratum (a low and continuous one, 6 to $10 \mathrm{~m}$ high, and another discontinuous with isolated individuals exceptionally exceeding $12 \mathrm{~m}$ in height), a relatively poor shrub stratum, and a relatively well developed herbaceous stratum (Matteucci 2012). Historically these woodlands have undergone different alterations, being subjected to logging, selective extraction of dominant species for poles, wood, firewood, and charcoal, as well as overgrazing by livestock and the replacement of native trees with fast-growing exotic species plantations (Johnson and Zuleta 2013). Moreover, in recent decades, intensive agriculture has advanced on the remaining woodland, producing woodland loss and fragmentation (Arturi 2006; Matteucci 2012). The climate is warm and humid, with an average annual temperature of $20^{\circ} \mathrm{C}$ and annual rainfall exceeding $1200 \mathrm{~mm}$. The precipitation is concentrated from the austral spring through summer to early fall (from October to April); however, there is usually a water deficit in the soil (due to high temperatures) during this period of the year (Matteucci 2012).

\section{Experimental design}

We set up twenty-four sampling blocks: 14 blocks set on the PSM between December 2014 and May 2016, and another 10 blocks set in the REA between May 2015 and May 2016. Each block consisted of a native woodland area and an adjacent deforested area. We set seed traps consisting of $0.5 \times 0.5 \mathrm{~m}$ "mosquito net" plastic fabric (mesh size of $1.5 \mathrm{~mm}$ ), raised from the ground $0.25 \mathrm{~m}$ with galvanized wire structures to prevent predation of the seeds by rodents (García et al. 2010). In each sampling block, two traps were placed within the native woodland area ("woodland" treatment) separated from each other by two meters, and two traps in the deforested area. Within the deforested area, one of the traps was placed under an artificial perch built with a 2-meter high bamboo pole and two wooden rods one meter long and $5 \mathrm{~mm}$ in diameter, crossed together and tied to the top end of the pole ("perch" treatment). The other trap was placed in the open area ("open" treatment), two meters away from the axis of the pole of the artificial perch. Artificial perches were located at a distance between 10 and 40 meters from the edge of the native woodland area and separated by at least 25 meters away from the artificial perches of the contiguous 
sampling blocks (Online resource 1- Fig 1). The deforested area of the blocks has undergone diverse uses (extraction of dominant species, extensive cattle ranching, small-scale agriculture, and firewalls). However, in both sites the soil was well conserved, covered by grass and herbaceous species (not bare, compacted, under limited drainage, or invaded by exotic grass species).

We collected seeds in the traps every 21 days. Whole fruits were discarded, and only seeds that had been dispersed by birds were analyzed. Since there are no frugivorous bats confirmed in the study area (Barquez and Díaz 2020), the possibility of confusing bird feces with bat feces was ruled out. The samples were dried on a stove for 60 minutes at $80^{\circ} \mathrm{C}$ to remove moisture and stored in paper envelopes. Seeds found in the traps were identified at the species level under a stereomicroscope (Nikon SMZ645, with magnification up to $50 \mathrm{X}$ ). For this purpose, a reference collection was made with seeds of fleshy fruits species collected within the study area. We additionally reviewed specimens of the Instituto de Botánica Darwinion herbarium and consulted bibliographic material (Alzugaray and Carnevale 2009; Abraham de Noir and Bravo 2014). For each species of seed, we recorded the origin (native and nonnative) and habit (tree, shrub, vine, or herb). Further, two types of habit were considered: type 1 included trees and shrubs with erect stems (woody species that can act as natural perches), while type 2 included vines and herbs. Seeds that could not be identified were considered as morphospecies only if seemed to come from fruits dispersed by birds (showing no signs of adaptation to anemochory or epizoochory).

\section{Data analysis}

To assess the effect of artificial perches on the abundance and species richness of seed rain reaching deforested areas, generalized linear mixed models were used. The abundance model included negative binomial distribution and log link function, while a normal distribution was used in the case of the species richness model (Crawley 2007; Zuur et al. 2009; Logan 2010). Treatment (woodland, perch, and open) was included as a fixed factor. Seed traps $(n=2)$, sampling blocks $(n=10$ and 14$)$ nested within the sites (PSM and REA) were included in the model as random factors.

We compared seed composition in the different treatments (woodland, perch, and open) analyzing the relative abundance of each species per sample. We conducted an ordination with Euclidean dissimilarity values calculated by a non-metric multidimensional scaling (NMDS) and a permutational multivariate analysis of variance, using the metaMDS and adonis functions of the "vegan" package in R (Oksanen et al. 2017).

We analyzed the effect of artificial perches on the seeds abundance and species richness according to the origin of plants (native or non-native) using generalized linear mixed models inflated in zeros with normal distribution for both variables (in this case morphospecies were removed from the data set). The model included treatment (woodland, perch, and open), the origin of species (native or non-native), and their interaction as fixed factors. Finally, we analyzed the possible effect of artificial perches on the colonization of woody species that can act as natural perches. The relative seed abundance and the species richness for both types of habit (trees and shrubs or vines and herbs) were calculated for each sample and generalized linear mixed models inflated in zeros with normal distribution were used for both 
variables, with treatment, type of habit and their interaction as fixed factors. All models were evaluated according to the AIC (Burnham and Anderson 2002). Statistical analyses were carried out using the "glmmTMB" package in R (Fournier et al. 2012; Skaug et al. 2013; Magnusson et al. 2016; R Development Core Team 2018).

\section{Results}

\section{Abundance and species richness in seed rain}

The abundance of seeds that reached artificial perches in the deforested area was higher compared to woodland treatment, while in the open area without perches the seed abundances decreased significantly (Fig 2. a). The model that best explained the variation in seed abundance included treatment (woodland, perch, and open) as the explanatory variable (Table 1), as opposed to the null model (Online Resource 1Table 1).

Species richness in the seed rain was similar in the perches and woodland treatment, while in the open area treatment was lowest (Fig. 2. b). The model that best explained the variation in species richness in seed rain included treatment (woodland, perch, and open) as the explanatory variable (Table 1), as opposed to the null model (Online Resource 1- Table 1).

\section{Species composition of seed rain}

Seed rain in the woodland and the artificial perches were similar in terms of their composition, as it is shown in the ordering of NMDS points (Online resource 1- Fig 2). A very small percentage of variation in the composition in seed rain was explained by the different treatments $\left(R^{2}=0.03\right.$, Online Resource 1Table 2).

Within the woodland, the abundance of native species was $30.51 \%$ of the total identified seeds, under artificial perches $24.67 \%$ and in open area traps $10 \%$. Results of the GLMM indicate that this trend in the seed dispersal is general and does not appear to be linked to one of the treatments (Table 2 and Online Resource 1-Table 3). In the case of artificial perches particularly, non-native seeds increase their abundance along the year with a maximum peak from October to December, while native seeds have their maximum peak from January to June and decrease their abundance along the year (Fig. 3). Despite nonnative seed abundance was higher than native seed abundance in all treatments, non-native species richness was lower than native species richness. In the woodland, there were 23 native species of seeds while only five were non-native species. In the deforested area under artificial perches, there were 13 native species and six non-natives species. In the open area treatment seeds from only two species were identified, one was native and the other non-native. Results of the GLMM for species richness concerning the origin indicate that in both treatments, artificial perches and open area traps, there was a significant decrease of native species richness (Table 2 and Online Resource 1- Table 3). 
Results of GLMM for the type of habit indicate that type 1 species (trees and shrubs with erect stems) significantly increase the abundance in seed rain; however, in the treatment without perches, the abundance of seeds from this type decreases significantly (Table 3 and Online Resource 1- Table 4). For species richness, the model indicates that type 1 species increase the richness in seed rain significantly, nevertheless in the treatment without perches, the richness of this type of habit decreases significantly (Table 3 and Online Resource 1- Table 4).

\section{Discussion}

Artificial perches produced a significant increase in the abundance in the seed rain that reach deforested areas surrounding the Espinal woodland remnants. The abundance of seeds found under artificial perches indicates that these structures act as a focus of attraction for birds and promote their arrival, facilitating the entry of plant propagules and giving rise to seed nucleation points in areas that have lost woody cover (Zwiener et al. 2014). These results agree with those obtained by most restoration programs that have used artificial perches around the world (Guidetti et al. 2016). In the few studies that did not find a significant increase in seeds under artificial perches, the duration of sampling may have been insufficient, considering that birds require a certain period of adaptation to start using these structures (Shiels and Walker 2003). Predation of dispersed seeds by other animals was also considered another possible cause (Holl 1998). Increasing abundance in seed rain in deforested areas is crucial, especially given that having a nearby source of propagules does not always imply a bigger seed rain and, in addition to that, a large proportion of the seeds arriving in the area do not survive until germination (Graham and Page 2012; Reid and Holl 2013). Therefore, the use of artificial perches then results in higher plant densities than projects based on passive restorations (Tres and Reis 2009; Schorn et al. 2010).

The installation of artificial perches also produced a significant increase in species richness compared to seed rain in deforested areas without perches. Perches give temporal and spatial continuity to the diverse interactions between frugivorous birds and plants in the forest, enabling, for example, the dispersal of rare species seeds by anti-apostatic selection, an important mechanism that structures the diversity of forests in recovery (Karubian et al. 2012; Carlo and Morales 2016). Thus, the seed rain under perches reflects in part the reproductive potential of endozochoric plants (Guimarães et al. 2008). Nevertheless, the process of seed dispersal from the woodland to the open area involves not only fruit consumption but also the movement of the birds. In this sense, there are some forest visitors or habitat generalists species more adapted to the conditions in deforested areas, but forest specialist species may refuse to cross the edge of the woodland, dispersing seeds mostly in the forest interior or flying straight ahead directly to another forest remnant (Bennun et al. 1996; García et al. 2010; Pizo and dos Santos 2010; Carlo et al. 2013). Generally, frugivorous bird species with non-specialized diets (species that consume fruits based on their availability in the environment) are the ones that are habitat generalists, making the most important seed dispersal among different environments (Purificação et al. 2014). This characteristic of the frugivorous bird assemblage can be the reason for the diminution of the seed species richness observed in the artificial perches in comparison to the woodland treatment. It is expected that as the 
development of secondary forest patches progresses in the deforested areas, more forest specialists and obligate frugivorous species will begin to move within the forest, increasing much more the species richness in the seed rain also there (Schleuning et al. 2011a; García and Martínez 2012; Bomfim et al. 2018).

Seed composition under artificial perches was similar to that of the woodland. Since seed flow is established from the neighboring woodland remnants, perches can promote vegetation similar to the original ecosystem (Schorn et al. 2010). Considering that the identity of the seed rain species has decisive effects on the natural succession of the sites, the control in the seeds' dispersal of non-native species could be one of the factors that seriously condition the use of artificial perches. It is quite common for invasive species to produce large amounts of fruits (Gleditsch and Carlo 2011). Here, the dispersal of non-native species was high in all treatments, even within the woodland. The noticeable difference between native and non-native species abundance was strongly influenced by the quantity of Morus alba (Common Mulberry; Moraceae) dispersed seeds. This species has a large number of seeds per fruit ( $56.8 \pm 15.7)$ and a large number of fruits per adult tree (1000-10000, SD, pers. obs.), ripen at the studied area from October to early December (SD, pers. obs.). But, while the abundance of native seeds did not decrease significantly outside the woodland, the richness of native species did. Again, the reason for the difference observed between the species richness in the artificial perches and the woodland treatment could be the movement of occasional or opportunistic frugivorous being attracted to the woodland when the amount of exotic fruits increases abruptly or tracking the presence of others across the foraging landscape (Carlo et al. 2007; Purificação et al. 2014). Instead, obligate frugivorous species get involved in much more interactions to sustain their basic metabolic requirements and have more selective foraging behaviors (Schleuning et al. 2011a; Sebastian-Gonzalez 2017; Bomfim et al. 2018), but do not leave the forest as frequently (Purificação et al. 2014), increasing the seed rain species richness of native plants inside the woodland. However, thinking about the possibilities of ecological restoration is interesting to state that several non-native species differ on the fruiting season with native (Gosper 2004; White and Vivian-Smith 2011). In the study area, the fruiting peak for non-native fleshy fruit species was detected from October to December, while for the native species the peak is between January and February and another occurs between May and June (Scarpa 2013). So, installation of artificial perches could be carried out if species with fleshy fruits in nearby woodland remnants are well recognized, avoiding sites where non-native species are present or placing them only at the time of the year when the invasive species have fewer fruits (Prather et al. 2017).

A large proportion of the seeds that reached the site favored by the artificial perches in the experimental area were woody plant species, as it has also been found by Prather et al. (2017) in Houston, USA. In this sense, artificial perches act in a similar way to isolated trees and remnant shrubs that persist to disturbance, accelerating the colonization of woody species below and around their canopy (Slocum 2001; Schlawin and Zahawi 2008). After developing, these trees or erect shrubs could act as natural perches for birds and successively improve conditions in the deforested area (providing shade, food, and nesting sites). Regeneration in deforested areas appears to be irregular and dependent on the formation of vegetation groups or nuclei that facilitate the recruitment of seeds from the forest, the establishment 
of new seedlings, and the expansion of woody plant cover (Carlo and Morales 2016). The influence of these nuclei continues even in later successional stages, showing a higher density of trees, basal area, and species richness in their vicinity (Slocum 2001; Schlawin and Zahawi 2008).

The experience states that artificial perches for birds are easy to implement, require little labor for manufacture and installation, and have substantially low costs, taking into account that they can be manufactured from materials recycled or found in the site (Holl 1998; Reis et al. 2010; Graham and Page 2012). In the future, it would be interesting to analyze what happens with more complex perches, or with a grouped arrangement of perches, since large nuclei are proven to be more attractive to birds (Holl 1998; Toh et al. 1999; Corbin and Holl 2012) and here only the simplest model has been studied. Perches seem to be a possible alternative when there are remnants of woodland in the proximity of the open area. It would also be interesting to study the optimal distances relative to the edge of the remnant for which perches are most effective in the Espinal (Pizo and dos Santos 2010). Nevertheless, while a big challenge of restoration in deforested areas is to attract birds to deposit seeds, there can be other barriers to plant regeneration (Holl et al. 2000; Reid and Holl 2013). For that reason, we considered that artificial perches may be much more successful in ecosystems that are sufficiently resilient and just need minimal intervention. Subtropical and temperate environments with disturbance matrices similar to the ones considered here have shown a significant increase in seedlings established under artificial perches (Guidetti et al. 2016). The soil and environmental conditions (low elevation, warm temperatures, and abundant rainfall) during and immediately after the period of highest native seeds dispersal at the experimental sites are expected to favor germination and seedling growth (Holl 2013). Further, both sites were located in protected areas, making the commitment of stopped disturbances and ensuring that care can be prolonged in time. In other contexts, additional measures and multiple approaches (such as soil transposition or livestock exclusion) may be required (Bevilacqua Marcuzzo et al. 2013).

In conclusion, artificial perches function as a nucleation technique to increase seeds dispersal by birds in deforested areas around Espinal woodland remnants. Artificial perches increased the abundance and species richness in the seed rain, with a species composition similar to that of the woodland. Using artificial perches should be avoided in sites with potentially invasive non-native species. However, in places where native and non-native species show different fructification peaks, artificial perches could be used in certain periods of the year, avoiding the dispersal of undesirable seeds of invasive species. In addition, artificial perches principally facilitate the arrival of woody species that then also serve as natural perches; this can progressively improve the conditions in the deforested area, having a positive impact even in later successional stages.

\section{Declarations}

\section{Funding}

For this work Brenda Guidetti received financial support provided by the Consejo Nacional de Investigaciones Científicas y Técnicas (CONICET), Argentina; the Instituto Nacional Tecnología 
Agropecuaria (INTA), Argentina and Idea Wild Foundation. The funders had no role in study design, data collection and analysis, decision to publish, or preparation of the manuscript.

\section{Conflicts of interest/Competing interests}

We declare and confirm that the present manuscript has been approved by all co-authors as well as by the responsible authorities. We also declare no conflicts of interests.

\section{Availability of data and material}

All the data is available in appendix of supplementary information

\section{Code availability}

Not applicable

\section{Authors' contributions}

Brenda Guidetti, Sebastián Dardanelli and Guillermo Amico contributed in manuscript conceptualization and experiment methodology, Brenda Guidetti and Fátima Miño did the field work and data curation, Brenda Guidetti performed the formal analysis, validation, data visualization, writing and original draft preparation, Sebastián Dardanelli and Guillermo Amico worked on the project administration, the supervision, review and editing. All authors read and approved the final manuscript.

\section{Acknowledgments}

The permit for field research was granted by Dirección General de Recursos Naturales Entre Ríos (DGRN), in Authorization $\mathrm{N}^{\circ}$. 003/15 (File $\mathrm{N}^{\circ}$. 1.733.195). We thank director Alfredo Berduc from Parque General San Martín, and Valeria Tiropolis, Viviana Fussi and Alba Flores from Reserva de Uso Múltiple Escuela J.B. Alberdi. Special thanks to Rubén G. who assisted us for perches construction and during field work. We also thank Claudia Alzugaray, Cesar Massi, Geraldina Richard and Berenice Schneider for helping in some seed species identification. We thank Romina Vidal-Russell for English revision of the manuscript.

\section{References}

1. Abraham de Noir F, Bravo S (2014) Frutos de leñosas nativas de Argentina, 1a edn. Universidad Nacional de Santiago del Estero - Facultad de Ciencias Forestales, Santiago del Estero

2. Alzugaray C, Carnevale N (2009) Libro de semillas de especies leñosas autóctonas, 1a edn.

3. Arturi M (2006) Situación ambiental en la Ecorregión Espinal. In: La situación ambiental argentina 2005. pp 241-260

4. Barnea A, Yom-Tov Y, Friedman J (1992) Effect of frugivorous birds on seed dispersal and germination of multi seeded fruits. Acta Oecologica - Int. J. Ecol. 13:209-219

5. Barquez RM, Díaz MM (2020) Nueva guía de los murciélagos de Argentina, 1st edn. Yerba Buena 
6. Bennun L, Dranzoa C, Pomeroy D (1996) The Forest Birds of Kenya and Uganda. J East African Nat Hist 85:23-48 . https://doi.org/10.2982/0012-8317(1996)85[23:tfboka]2.0.co;2

7. Bevilacqua Marcuzzo S, Ganade G, Machado Araujo M, Brião Muniz MF (2013) Comparação da eficácia de técnicas de nucleação para restauração de área degradada no Sul do Brasil. Floresta 43:39-48

8. Bomfım JDA, Guimarães Jr PR, Peres CA, Carvalho G, Cazetta E (2018) Local extinctions of obligate frugivores and patch size reduction disrupt the structure of seed dispersal networks. Ecography (Cop) 41:1-11 . https://doi.org/10.1111/ecog.03592

9. Burnham KP, Anderson DR (2002) Model selection and multi-model inference: A practical-theoretical approach, 2nd edn. Springer-Verlag

10. Carlo TA, Aukema JE, Morales JM (2007) Plant-frugivore interactions as spatially explicit networks: Integrating frugivore foraging with fruiting plant spatial patterns. In: Dennis A (ed) Seed dispersal: Theory and its application in a changing world. pp 369-390

11. Carlo TA, García D, Martinez D, Gleditsch J, Morales JM (2013) Where do seeds go when they go far? Distance and directionality of avian seed dispersal in heterogeneous landscapes. Ecology 94:301307

12. Carlo TA, Morales JM (2016) Generalist birds promote tropical forest regeneration and increase plant diversity via rare-biased seed dispersal. Ecology 97:1819-1831 . https://doi.org/10.1890/15-2147.1

13. Corbin JD, Holl KD (2012) Applied nucleation as a forest restoration strategy. For Ecol Manage 265:37-46 . https://doi.org/10.1016/j.foreco.2011.10.013

14. Corlett RT, Hau BCH (2000) Seed dispersal and forest restoration. For Restor Wildl Conserv 317-325

15. Cottee-Jones HEW, Matthews TJ, Bregman TP, Barua M, Tamuly J, Whittaker RJ (2015) Are protected areas required to maintain functional diversity in human-modified landscapes? PLoS One 10:1-22 . https://doi.org/10.1371/journal.pone.0123952

16. Crawley MJ (2007) The R book. Wiley, Chichester, UK

17. Cubiña A, Aide TM (2001) The effect of distance from forest edge on seed rain and soil seed bank in a tropical pasture. Biotropica 33:260-267

18. Da Silveira NS, Niebuhr BBS, Muylaert RDL, Ribeiro MC, Pizo MA (2016) Effects of land cover on the movement of frugivorous birds in a heterogeneous landscape. PLoS One 11:1-19 . https://doi.org/10.1371/journal.pone.0156688

19. Debussche M, Isenniann P (1994) Bird-dispersed seed rain and seedling establishment in patchy Mediterranean vegetation. Oikos 3:414-426

20. Donald PF, Evans AD (2006) Habitat connectivity and matrix restoration: the wider implications of agri-environment schemes. J Appl Ecol 43:209-218 . https://doi.org/10.1111/j.13652664.2006.01146.x

21. Elgar AT, Freebody K, Pohlman CL, Shoo LP, Catterall CP (2014) Overcoming barriers to seedling regeneration during forest restoration on tropical pasture land and the potential value of woody 
weeds. Front Plant Sci 5:1-10 . https://doi.org/10.3389/fpls.2014.00200

22. Foley JA, Ramankutty N, Brauman KA, Cassidy ES, Gerber JS, Johnston M, Mueller ND, O'Connell C, Ray DK, West PC, Balzer C, Bennett EM, Carpenter SR, Hill J, Monfreda C, Polasky S, Rockström J, Sheehan J, Siebert S, Tilman D, Zaks DPM (2011) Solutions for a cultivated planet. Nature 478:337342 . https://doi.org/10.1038/nature10452

23. Fournier D, Skaug H, Ancheta J, lanelli J, Magnusson A, Maunder M, Nielsen A, Sibert J (2012) AD Model Builder: using automatic differentiation for statistical inference of highly parameterized complex nonlinear models. Optim Methods Softw 27:233-249

24. García D, Martínez D (2012) Species richness matters for the quality of ecosystem services: a test using seed dispersal by frugivorous birds. Proc R Soc B Biol Sci 279:3106-3113 . https://doi.org/10.1098/rspb.2012.0175

25. García D, Zamora R, Amico GC (2010) Birds as suppliers of seed dispersal in temperate ecosystems: Conservation guidelines from real-world landscapes. Conserv Biol 24:1070-1079 . https://doi.org/10.1111/j.1523-1739.2009.01440.x

26. Gleditsch J, Carlo TA (2011) Fruit quantity of invasive shrubs predicts the abundance of common native avian frugivores in central Pennsylvania. Divers Distrib 17:244-253

27. Gosper CR (2004) Fruit characteristics of invasive bitou bush, Chrysanthemoides monilifera (Asteraceae), and a comparison with co-occurring native plant species. Aust J Bot 52:223-230

28. Graham LLB, Page SE (2012) Artificial bird perches for the regeneration of degraded tropical peat swamp forest: A restoration tool with limited potential. Restor Ecol 20:631-637 . https://doi.org/10.1111/j.1526-100X.2011.00805.x

29. Green R, Dennis A (2007) Management implications and conservation. In: Dennis A, Schupp EW, Green $R$, Westcott $D$ (eds) Seed dispersal: Theory and its application in a changing world. $C A B$ International

30. Griscom HP, Ashton MS (2011) Restoration of dry tropical forests in Central America: A review of pattern and process. For Ecol Manage 261:1564-1579 .

https://doi.org/10.1016/j.foreco.2010.08.027

31. Guevara S, Meave J, Moreno-Casasola P, Laborde J (1992) Floristic composition and structure of vegetation under isolated trees in neotropical pastures. J Veg Sci 3:655-664 . https://doi.org/10.2307/3235833

32. Guidetti BY, Amico GC, Dardanelli S, Rodriguez-Cabal MA (2016) Artificial perches promote vegetation restoration. Plant Ecol 217:935-942 . https://doi.org/10.1007/s11258-016-0619-4

33. Guimarães PR, Galetti M, Jordano P (2008) Seed dispersal anachronisms: Rethinking the fruits extinct megafauna ate. PLoS One 3: . https://doi.org/10.1371/journal.pone.0001745

34. Hardwick K, Healey JR, Elliott S, Blakesley D (2004) Research needs for restoring seasonal tropical forests in Thailand: accelerated natural regeneration. New For 27:285-302 .

https://doi.org/10.1023/B:NEFO.0000022228.08887.d2 
35. Hobbs RJ, Arico S, Aronson J, Baron JS, Bridgewater P, Cramer VA, Epstein PR, Ewel JJ, Klink CA, Lugo AE, Norton D, Ojima D, Richardson DM, Sanderson EW, Valladares F, Vilà M, Zamora R, Zobel M (2006) Novel ecosystems: Theoretical and management aspects of the new ecological world order. Glob Ecol Biogeogr 15:1-7 . https://doi.org/10.1111/j.1466-822X.2006.00212.x

36. Holl KD (1998) Do bird perching structures elevate seed rain and seedling establishment in abandoned tropical pasture? Restor Ecol 6:253-261 . https://doi.org/10.1046/j.1526100X.1998.00638.x

37. Holl KD (2013) Restoring Tropical Forest. Nat Educ Knowl 4:4

38. Holl KD, Loik ME, Lin EH V, Samuels IA (2000) Tropical montane forest restoration in Costa Rica: overcoming barriers to dispersal and establishment. Restor Ecol 8:339-349

39. Huebner CD, Tobin PC (2006) Invasibility of mature and 15-year-old deciduous forests by exotic plants. Plant Ecol 186:57-68 . https://doi.org/10.1007/s11258-006-9112-9

40. Johnson BG, Zuleta GA (2013) Land-use land-cover change and ecosystem loss in the Espinal ecoregion, Argentina. Agric Ecosyst Environ 181:31-40 . https://doi.org/10.1016/j.agee.2013.09.002

41. Jones HP, Schmitz OJ (2009) Rapid recovery of damaged ecosystems. PLoS One 4: . https://doi.org/10.1371/journal.pone.0005653

42. Karubian J, Browne L, Bosque C, Carlo T, Galetti M, Loiselle BA, Blake JG, Cabrera D, Durães R, Labecca FM, Holbrook KM, Holland R, Jetz W, Kümmeth F, Olivo J, Ottewell K, Papadakis G, Rivas G, Steiger S, Voirin B, Wikelski M (2012) Seed dispersal by neotropical birds: emerging patterns and underlying processes. Ornitol Neotrop 23:9-24

43. Logan M (2010) Biostatistical Design and Analysis Using R

44. Magnusson A, Skaug H, Nielsen A, Berg C, Kristensen K, Maechler M, van Bentham K, Bolker B, Brooks M (2016) glmmTMB: Generalized Linear Mixed Models using Template Model Builder

45. Martínez-Garza C, Howe HF (2003) Restoring tropical diversity: Beating the time tax on species loss. J Appl Ecol 40:423-429 . https://doi.org/10.1046/j.1365-2664.2003.00819.x

46. Mastrangelo ME (2014) Conservation on the frontier: understanding and influencing how cattle production impacts avian diversity in the Dry Chaco Forest of Argentina. Victoria University of Wellington

47. Matteucci SD (2012) Ecorregión Espinal. In: Morello J, Matteucci SD, Rodríguez AF, Silva M (eds) Ecorregiones y complejos ecosistémicos argentinos. $p 719$

48. McCay TS, McCay DH, Czajka JL (2009) Deposition of exotic bird-dispersed seeds into three habitats of a fragmented landscape in the northeastern United States. Plant Ecol 203:59-67 . https://doi.org/10.1007/s11258-008-9509-8

49. McDonnell MJ, Stiles EW (1983) The structural complexity of old field vegetation and the recruitment of bird dispersed plant species. Oecologia 56:109-116

50. Nepstad DC, Uhl C, Pereira CA, Silva JMC da (1996) A Comparative Study of Tree Establishment in Abandoned Pasture and Mature Forest of Eastern Amazonia. Oikos 76:25-39 . 
https://doi.org/10.2307/3545745

51. Oksanen AJ, Blanchet FG, Friendly M, Kindt R, Legendre P, Mcglinn D, Minchin PR, O'Hara RB, Simpson GL, Solymos P, Henry M, Stevens H, Szoecs E, Wagner H (2017) Community Ecology Package

52. Pejchar L, Pringle RM, Ranganathan J, Zook JR, Duran G, Oviedo F, Daily GC (2008) Birds as agents of seed dispersal in a human-dominated landscape in southern Costa Rica. Biol Conserv 141:536544 . https://doi.org/10.1016/j.biocon.2007.11.008

53. Pizo MA, dos Santos BTP (2010) Frugivory, post-feeding flights of frugivorous birds and the movement of seeds in a Brazilian fragmented landscape. Biotropica 43:335-342 . https://doi.org/10.1111/j.1744-7429.2010.00695.x

54. Ponce AM, Grilli G, Galetto L (2012) Frugivoría y remoción de frutos ornitócoros en fragmentos del bosque chaqueño de Córdoba (Argentina). Bosque 33:33-41 . https://doi.org/10.4067/S071792002012000100004

55. Prather CM, Huynh A, Pennings SC (2017) Woody structure facilitates invasion of woody plants by providing perches for birds. Ecol Evol 7:8032-8039 . https://doi.org/10.1002/ece3.3314

56. Purificação KN, Pascotto MC, Pedroni F, Pereira JMN, Lima NA (2014) Interactions between frugivorous birds and plants in savanna and forest formations of the Cerrado. Biota Neotrop 14: . https://doi.org/10.1590/1676-06032014006814

57. R Development Core Team (2018) R: a language and environment for statistical computing

58. Reid JL, Holl KD (2013) Arrival \# Survival. Restor Ecol 21:153-155 . https://doi.org/10.1111/j.1526100X.2012.00922.x

59. Reis A, Campanhã Bechara F, Tres DR (2010) Nucleation in tropical ecological restoration. Sci Agric 67:129-251

60. Rocha-Santos L, Benchimol M, Mayfield MM, Faria D, Pessoa MS, Talora DC, Mariano-Neto E, Cazetta E (2017) Functional decay in tree community within tropical fragmented landscapes: Effects of landscape-scale forest cover. PLoS One 12:1-18 . https://doi.org/10.1371/journal.pone.0175545

61. Scarpa LJ (2013) Fenología reproductiva de plantas leñosas, nativas y exóticas, e interacciones con visitantes florales en un área protegida en el Espinal de Entre Ríos, Argentina. Universidad Nacional del Litoral

62. Schlawin JR, Zahawi RA (2008) ' Nucleating ' succession in recovering neotropical wet forests: The legacy of remnant trees. J Veg Sci 19:485-492 . https://doi.org/10.3170/2008-8-18387

63. Schleuning M, Blüthgen N, Flörchinger M, Braun J, Schaefer MH, Böhning-Gaese K (2011a) Specialization and interaction strength in a tropical plant - frugivore network differ among forest strata. Ecology 92:26-36

64. Schleuning M, Farwig N, Peters MK, Bergsdorf T, Bleher B, Brandl R, Dalitz H, Fischer G, Freund W, Gikungu MW, Hagen M, Garcia FH, Kagezi GH, Kaib M, Kraemer M, Lung T, Naumann CM, Schaab G, Templin M, Uster D, Wägele JW, Böhning-Gaese K (2011b) Forest fragmentation and selective 
logging have inconsistent effects on multiple animal-mediated ecosystem processes in a tropical forest. PLoS One 6:e27785 . https://doi.org/10.1371/journal.pone.0027785

65. Schorn LA, Krieger A, Canestraro Nadolny M, Bergamo Fenilli TA (2010) Avaliação de técnicas para indução da regeneração natural em área de preservação permanente sob uso anterior do solo com Pinus elliottii. Floresta 40:281-294

66. Sebastian-Gonzalez E (2017) Drivers of species' role in avian seed-dispersal mutualistic networks. J Anim Ecol 86:878-887

67. Sekercioglu CH (2007) Conservation ecology: Area trumps mobility in fragment bird extinctions. Curr Biol 17:R283-R286 . https://doi.org/10.1016/j.cub.2007.02.019

68. Shiels AB, Walker LR (2003) Bird perches increase forest seeds on Puerto Rican landslides. Restor Ecol 11:457-465 . https://doi.org/10.1046/j.1526-100X.2003.rec0269.x

69. Shoo LP, Catterall CP (2013) Stimulating natural regeneration of Tropical Forest on degraded land: approaches, outcomes, and information gaps. Restor Ecol 21:670-677 . https://doi.org/10.1111/rec.12048

70. Sione SMJ, Ledesma SG, Rosenberger LJ, Wilson MG, Sabattini RA (2016) Banco de semillas del suelo en un área de bosques nativos sujeta a cambio en el uso de la tierra (Entre Ríos, Argentina). Rev Fave, Ciencias Agrar 15:1-17

71. Skaug H, Fournier D, Nielsen A, Magnusson A, Bolker BM (2013) Generalized Linear Mixed Models using AD Model Builder

72. Slocum MG (2001) How tree species differ as recruitment foci in a tropical pasture. Ecology 82:2547-2559

73. Toh I, Gillespie M, Lamb D (1999) The role of isolated trees in facilitating tree seedling recruitment at a degraded Sub-Tropical rainforest site. Restor Ecol 7:288-297 . https://doi.org/10.1046/j.1526100X.1999.72022.x

74. Tres DR, Reis A (2009) Técnicas nucleadoras na restauração de floresta ribeirinha em área de Floresta Ombrófila Mista, Sul do Brasil. Rev Biotemas 22:59-71

75. White E, Vivian-Smith $G$ (2011) Contagious dispersal of seeds of synchronously fruiting species beneath invasive and native fleshy-fruited trees. Austral Ecol 36:195-202

76. WWF International (2005) Forest restoration in landscapes. Springer Science, New York

77. Zanini L, Ganade G (2005) Restoration of Araucaria Forest: The Role of Perches, Pioneer Vegetation, and Soil Fertility. Restor Ecol 13:507-514 . https://doi.org/10.1111/j.1526-100X.2005.00063.x

78. Zuur AF, leno EN, Walker NJ, Saveliev AA, Smith GM (2009) Mixed effects models and extensions in ecology with R. Springer Science

79. Zwiener VP, Cardoso FCG, Padial A a., Marques MCM (2014) Disentangling the effects of facilitation on restoration of the Atlantic Forest. Basic Appl Ecol 15:34-41. https://doi.org/10.1016/j.baae.2013.11.005 


\section{Tables}

Table 1 Abundance and richness of the seed rain in the different treatments (woodland, perch and open). Estimated parameters, standard error, $z$ value and $p$ value of variables for GLMMs selected according to the AIC criterion.

\section{Estimate Std. Error $z$ value $\operatorname{Pr}(>|z|)$}

\begin{tabular}{ccccc}
\hline Abundance & & & & \\
\hline (intercept) & 1.75 & 0.59 & 2.91 & 0.003 ** \\
\hline perch & 0.13 & 0.22 & 0.61 & 0.543 \\
\hline open & -4.53 & 0.32 & -13.90 & $<0.001$ *** \\
\hline Richness & & & & \\
\hline (intercept) & 0.69 & 0.16 & 4.20 & $<0.001$ *** \\
\hline perch & -0.13 & 0.05 & -2.34 & $0.019 *$ \\
\hline open & -0.96 & 0.05 & -12.51 & $<0.001$ ***
\end{tabular}

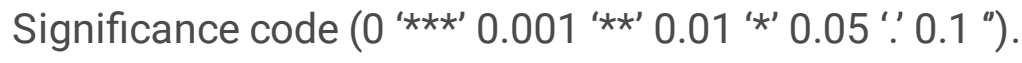

Table 2 Seed rain abundance and species richness according to plant origin (native and non-native). Estimated parameters, standard error, $z$ value, and $p$ value of explanatory variables for GLMMs selected according to the AIC criterion. 


\begin{tabular}{|cllll|}
\hline \multicolumn{1}{|c}{ Estimate } & Std. Error & $z$ value & $\operatorname{Pr}(>|z|)$ \\
\hline Abundance & & & & \\
\hline (intercept) & 24.82 & 3.62 & 6.86 & $<0.001$ *** \\
\hline open & -20.52 & 14.98 & -1.37 & 0.171 \\
\hline perch & -2.61 & 4.43 & -0.59 & 0.556 \\
\hline native & -16.99 & 3.49 & -4.86 & $<0.001$ *** \\
\hline open : native & 17.61 & 24.31 & 0.72 & 0.469 \\
\hline perch : native & 10.59 & 6.94 & 1.52 & 0.127 \\
\hline Richness & & & & \\
\hline (intercept) & 0.67 & 0.14 & 4.69 & $<0.001 * * *$ \\
\hline open & -0.56 & 0.08 & -6.63 & $<0.001 * * *$ \\
\hline perch & -0.02 & 0.07 & -0.26 & 0.797 \\
\hline native & $\mathbf{0 . 4 8}$ & 0.06 & 7.78 & $<0.001$ *** \\
\hline open : native & -0.51 & 0.11 & -4.58 & $<0.001$ *** \\
\hline perch : native & -0.49 & 0.11 & -4.20 & $<0.001 * * *$ \\
\hline
\end{tabular}

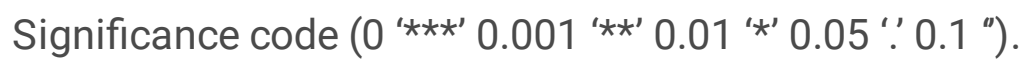

Table 3 Seed rain abundance and species richness according to types of habit (type 1 including trees and shrubs and type 2 including vines and herbs). Estimated parameters, standard error, $z$ value, and $p$ value of the explanatory variables for GLMMs selected according to the AIC criterion. 


\begin{tabular}{|c|c|c|c|c|}
\hline & Estimate & Std. Error & $z$ value & $\operatorname{Pr}(>|z|)$ \\
\hline \multicolumn{5}{|l|}{ Abundance } \\
\hline (intercept) & 0.10 & 0.05 & 1.92 & 0.054 \\
\hline open & -0.10 & 0.02 & -4.86 & $<0.001 * * *$ \\
\hline perch & -0.04 & 0.02 & -1.81 & 0.069 . \\
\hline type 1 & 0.23 & 0.02 & 14.81 & $<0.001 * \star *$ \\
\hline open: type 1 & -0.21 & 0.03 & -7.23 & $<0.001 * * *$ \\
\hline perch: type 1 & -0.02 & 0.03 & -0.66 & 0.506 \\
\hline \multicolumn{5}{|l|}{ Richness } \\
\hline (intercept) & 0.10 & 0.05 & 2.09 & 0.036 * \\
\hline open & -0.11 & 0.02 & -5.35 & $<0.001 * \star \star *$ \\
\hline perch & -0.04 & 0.02 & -1.95 & 0.051 \\
\hline type 1 & 0.22 & 0.01 & 14.06 & $<0.001 * \star \star \star$ \\
\hline open: type 1 & -0.19 & 0.03 & -6.82 & $<0.001 * \star \star *$ \\
\hline perch: type 1 & -0.02 & 0.03 & -0.71 & 0.476 \\
\hline
\end{tabular}

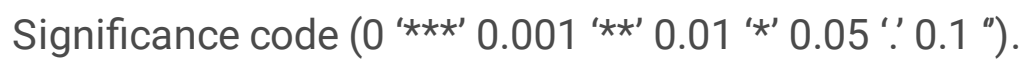

Figures 


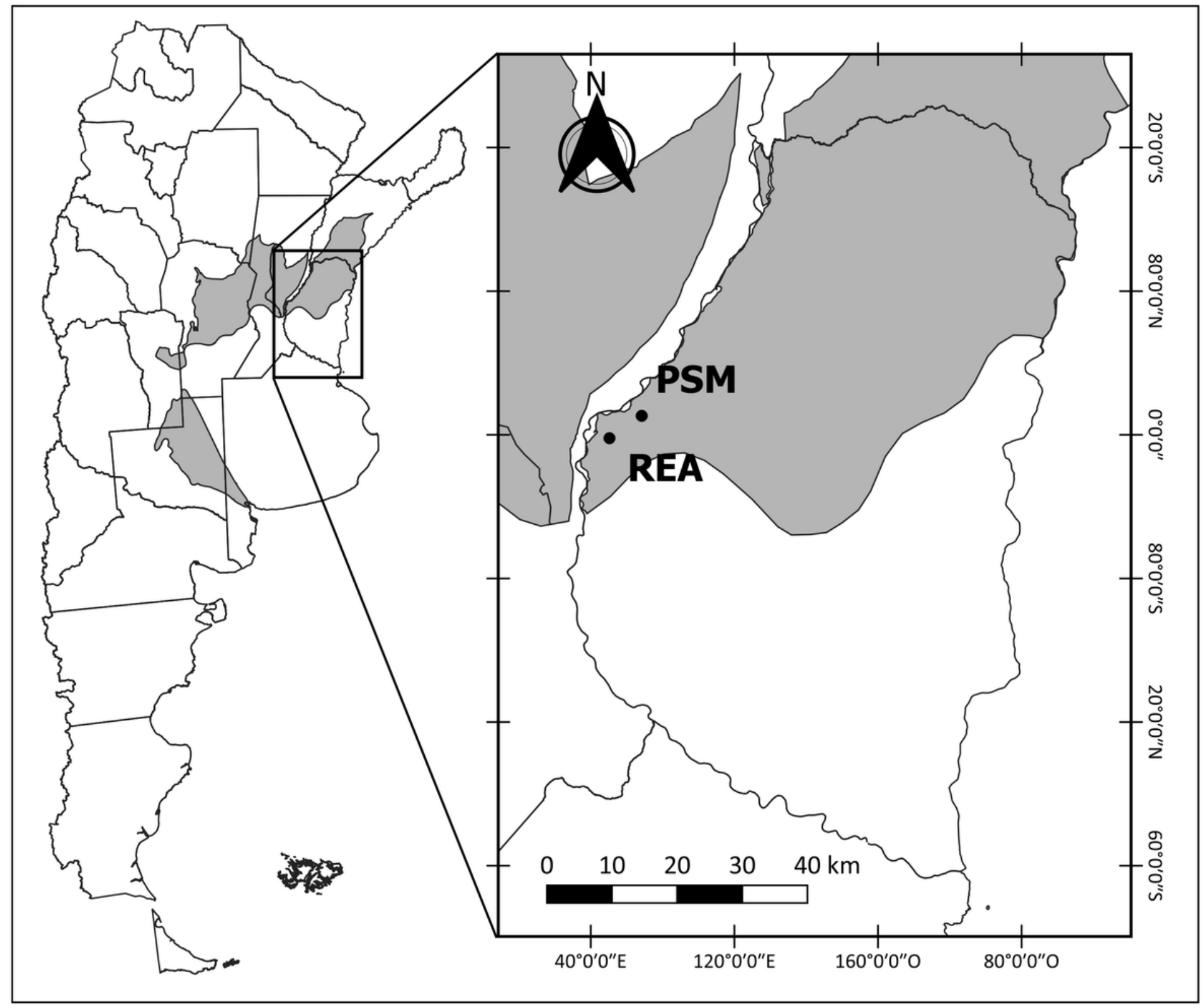

Figure 1

Map of Argentina showing the Espinal Ecoregion (shaded area) and both experimental sites (PSM and REA) located in the center of the Province of Entre Ríos. 

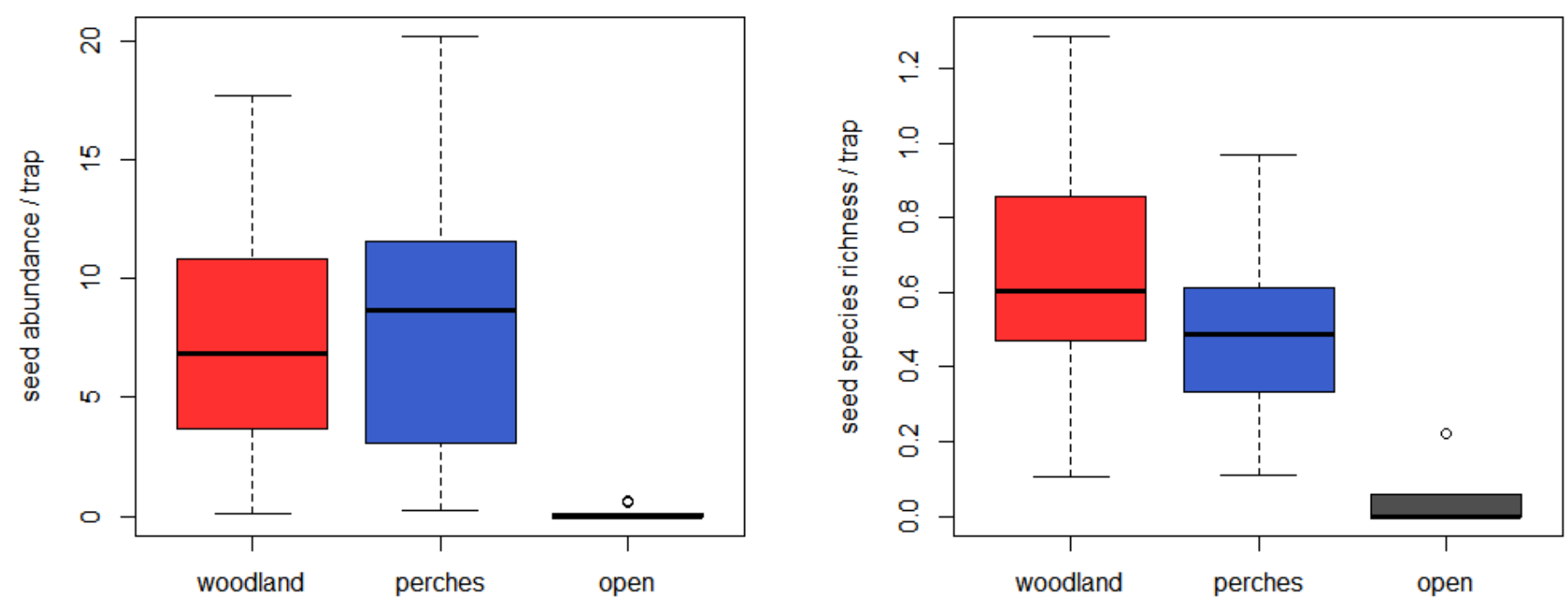

Figure 2

(a) Average abundance of seed rain per trap recorded every 21 days inside the woodland ( $n=5947)$, under the artificial perches $(n=2901)$ and in open area $(n=27)$. (b) Average species richness of seed rain per trap recorded every 21 days inside the woodland $(n=38)$, under the artificial perches $(n=29)$ and in open area $(n=6)$.

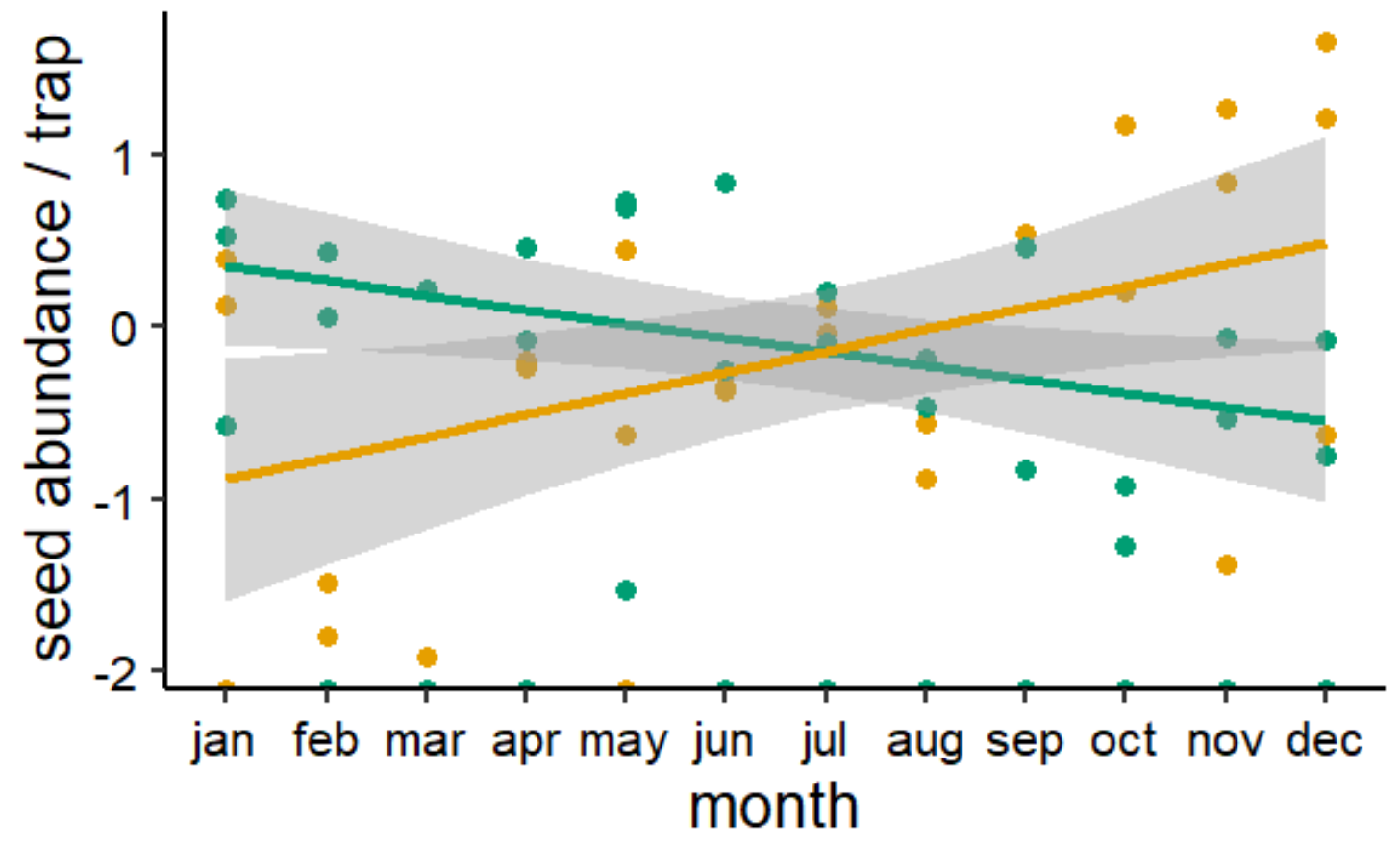

plant origin native non-native

Figure 3 
Temporal variation through the year in average seed abundance (log transformed) of native (green dots) and non-native (orange) species under artificial perches.

\section{Supplementary Files}

This is a list of supplementary files associated with this preprint. Click to download.

- Onlineresource1.Supplementarymaterial.pdf

- Onlineresource2.Datasetoftheseedrain.xlsx 